\title{
Review of Walking in Berlin: A Flaneur in the Capital by Franz Hessel
}

\author{
Michael Ackland
}

James Cook University

B erlin ist einer Reise wert-Berlin is worthy of a trip. With this slogan the former Bundesrepublik encouraged travellers to visit the then isolated, divided city. Since die Wende, or the turning-point and reunification of city and nation state in 1989, Berlin has long ceased to require special pleading. Attracted by its vibrancy, youth culture and history, visitors are not in short supply. They teem around sites associated with the Cold War, the Third Reich and the Hohenzollern imperial capital, and fondly reimagine the 1920s, when Berlin was a key centre of modernism, experimentation and sexual emancipation. But Allied bombers and attacking Soviet armies have left few traces of this notorious period-which makes Franz Hessel's Walking in Berlin: A Flaneur in the Capital (1929) both a valuable guide to actual times since elevated into legend and a last glimpse, as it were, of a world destined that very year to be shattered by the Wall Street Crash and the ineluctable rise to power of the Nazi Party.

Divided into chapters conceived of as separate walks, Hessel adopts a variety of vantagepoints to describe his native city. This enables him to reminisce, intermix memories from childhood and youth, adopt a persona like that of the tourist or largely ignorant outsider, and to shift between simple external descriptions and personalised minutiae. The perspective often seems that of a candid, objective observer, but this can camouflage more subtle purposes. The opening section "The Suspect," for instance, plays off the idle flaneur against the busy, diligent and profitably engaged. Unlike Baudelaire's flaneur who is one with the crowd and inconspicuous within it, his modern avatar is definitely an alien presence, followed repeatedly by "wary glances." Indeed, so aberrant is his behaviour among industrious citizens that he himself risks becoming a "spectacle," catalyst and potential matter for police attention. "Will she alert the law to this strange fellow's behaviour? Suspicious nature of the observer!" (p. 2). Here Hessel is not simply playing off idle leisure against manifestations of Weber's Protestant work ethic, but arguably beginning his peregrinations with a quirky acknowledgement of that local industriousness, so actively promoted by Hohenzollern policy that it became a hallmark of Prussian Berlin. Inheritors of territory with few natural resources, its rulers recognised that their subjects needed to be the major source of national well-being, and so took to dropping in on local craftsmen to reward their industry, or castigate sloth, like successive flaneurs avant la lettre. Consequently, the theme of industry recurs throughout the walks, climaxing in Hessel's rhetorical question: "Are they [the inhabitants of Berlin] ever at home in their leisure?" (p. 221). 
Unlike a monarch, the modern-day flaneur is quintessentially "unauthorized" (p. 3) and rarely welcome-in short, a dubious intruder whose status is summarised by a concluding anecdote. In an elevator, which "was a grim interloper in the once serenely wide stairwell" (p. 5), Hessel is accompanied by a canine in need of exercise. But before exiting, the dog "forgot himself" (p. 5). The flaneur's "complicity" is recognised, which draws forth the concierge's angry quip: "Eh? An' ya wanna be a cultured yuman being?" Deftly Hessel, a pronounced Francophile, identifies himself with modernity as well as values and behavioural codes far different from traditional Prussian pomp and parsimony, or with what passes for merde in the eyes of blinkered conservatives.

His preferred Berlin is that of the socalled "golden years" of the Weimar Republic (1924-1929) which, one curmudgeon gruffly claims, "only cares for the young people" (p. 4). And youth is repeatedly celebrated, though nowhere more clearly than in the section "Lust for Life." The dynamic changes that separate it from earlier generations are underscored by the opening acknowledgement that "enjoy[ing] things . . . doesn't come naturally to Germans" (p. 31). Whereas old-timers confuse pleasure with "accumulation, quantity, excess," our "new Berlin girls" cultivate at times a nonchalant, at times an edgy sophistication. Dancing is their passion (preferably all night and in diverse, in vogue locales), improving sports, stringent diets and meticulous self-projection its prelude. Wonderfully attired, intricately made-up and bronzed "comme il faut," these modern women offer a smorgasbord of "innocent bare flesh, enticing concealments, and grotesque exaggerations in which to hide themselves away," set off by "turbans and feathered caps" (p. 33). Here too transvestites, intimate same-sex couples and cross-dressers move freely, the once "bold protest" now "become a rather harmless pleasure" (p. 43). In comparison the young men are positively uninteresting, still sporting "side-whiskers" or, if modishly inclined, having merely "the back of his head . . shaved in the American style" (p. 32). Supernumeraries at best, they dwindle into insignificance beside modern women who smoke and drink freely, drive themselves down fashionable Budapester Straße, "traipse over glass plate" into the best hotels, and have a connoisseur's appreciation of menus, venues and Berlin's varied celebrities. Hessel is a decided friend and admirer of female emancipation, and especially of those daughters "who've become world-travellers and conquerors in the meantime" (p. 39).

Ultimately his Berlin is one packed with incidents and details that invite meditation. At the outset, in a cross between a haberdashery and "stocking repair shop," he reveals his preferred mode of perception: "I'm allowed to look closely at all of it, and glean a piece of the city's and the world's history from it, while the women confer" (p. 4). To see world-history in a mundane detail, and epochal emancipation in a painted smile-such is the mindset that offers to accompany us for 250 pages. Prussian Berlin wins plaudits for classically inspired architecture and noble institutions, but not for its heel-clicking and iterated statues of military paragons. Wilhelmine Germany is verbally pummeled, its pompous buildings at times deemed worthy of demolition. Instead Hessel celebrates modern innovation, be it in the gleaming chrome of new vehicles or factories that are veritable "temples of machinery" (p. 15). He applauds the latest forms of industrialisation (production "without the touch of humankind") and commodification. Praise is spread even-handedly between "great halls of iron and electricity" (p. 18) and their 
consumer counterparts in "incandescent . . . gigantic department store[s]" (p. 26)-destined to be aryanised under Hitler, with household names like Tietz and Wertheim erased permanently from local vocabularies. Similarly liberated, modern German womanhood would soon be regimented and standardized, their uniforms complemented by "mind-forg'd manacles."

Fortunately Hessel is spared such dark foreknowledge. Politics rarely intrudes into the narrative. Post-war, revolutionary stirrings rate three brief mentions, and readers are offered a glimpse of explosive tensions between Communists and Nazis during gatherings in the Sportpalast (pp. 247-248). But these are presented as passing incidents in a rich, everchanging panorama. Hessel's Berlin is still permissive, open-minded and largely slogan freeunable to imagine the bigotry, torchlight parades and burning books that would soon help make Goebbel's fiefdom the recognised "Hauptstadt der Bewegung," or the capital of National Socialism and birthplace of what one of Berlin's most recent museums has dubbed "the topography of terror." In the handful of "golden years" between hyper-inflation and the Great Depression, the Weimar Republic seemed to have a future, and Hessel captures its diversity, inequalities, contradictions and hopes in an almost pitch-perfect picture of mid-1920s' Berlin.

Walking in Berlin: A Flaneur in the Capital by Franz Hessel (trans. Amanda DeMarco) by Scribe Publications (2016). RRP \$29.99 AUD, ISBN 9781925307337. 